\title{
FREE-FLOATING THROMBUS IN THE CAROTID ARTERY: TWO DIFFERENT ETIOLOGIES AND TREATMENT APPROACHES
}

\author{
Çetin Kürşad AKPINAR*, Atilla Özcan ÖZDEMİ*** \\ *Samsun Training and Research Hospital, Neurology Clinic, Interventional Neurology Department, \\ Samsun, TURKEY \\ **Eskisehir Osmangazi University Medical Faculty, Department of Neurology, Neurocritical Care and \\ Interventional Neurology Department, Eskisehir, TURKEY
}

\begin{abstract}
Free floating thrombosis (FFT) of carotid artery (internal and/or common) is a rare condition among carotid artery diseases which can lead to acute ischemic stroke or recurrent transient ischemic attacks.FFT is a quite rare and their pathophysiology has not yet been clarified.The treatment management of FFT in the acute ischemic stroke is controversial. In this article, we presented free floating thrombi cases with two different etiological causes in which we followed two different (medical and endovascular) treatment approaches.
\end{abstract}

Key Words: Acute stroke, carotid artery, diagnosis, etiology, free floating thrombosis, treatment.

\section{KAROTID ARTERDEKI HAREKETLİ TROMBÜS: İKI FARKLI ETIYOLOJI VE TEDAVI YAKLAŞIMI}

\section{ÖZET}

Karotid arterdeki (internal ve/veya kommon) hareketli trombüs, karotid arter hastalıkları arasında akut iskemik inme ya da tekrarlayan geçici iskemik ataklara neden olan nadir bir durumdur.Hareketli trombüs oldukça nadirdir ve patofizyolojisi henüz aydınlatılamamıștır.Akut iskemik inmede hareketli trombüsün tedavi yönetimi tartışmalıdır.Biz bu yazıda, iki farklı etiyolojik nedeni olan ve iki farklı tedavi yaklaşımı izlediğimiz (medikal ve endovasküler) hareketli trombüs olgusu sunduk.

Anahtar Sözcükler: Akut inme, etiyoloji, karotid arter, hareketli trombüs, tanı, tedavi.

\section{INTRODUCTION}

Free-floating thrombus in the carotid artery is a rare but important cause of embolic strokes (1). Although digital subtraction angiography (DSA) is the gold standard for diagnosis, the carotid ultrasonography is more valuable in demonstrating free-floating thrombus (2). It is twice as common in men as in women (1-4). The clinical picture usually begins acutely (in more than $90 \%$ of cases) and often causes recurrent transient ischemic attacks and acute stroke due to artery-to-artery distal embolism (microembolism). Atherosclerosis and hypercoagulation are the most frequently accused causes in the etiology (6-9).

The possible pathogenic mechanism of free-floating thrombus is the formation of thrombus formation in that region as a result of intra-plaque hemorrhage or rupture of atherosclerotic plaque $(7,8)$. There is no clear consensus on the treatment strategy [medical, surgical (endarterectomy), endovascular treatment]. Case reports showed that intravenous (IV) unfractionated heparin treatment initiated in the early period reduced recurrence in stroke cases that developed depending on hypercoagulation, dissection and intraluminal arterial thrombus (10). In this article, we presented free-floating thrombus cases that have two etiologic factors and to which two different treatment approaches were applied.

Corresponding author: Assoc. Prof. Çetin Kürşad Akpınar, MD. Samsun Training and Research Hospital, Neurology Clinic, Interventional Neurology Department, Samsun, TURKEY.

Phone: +90362311 $1500 \quad$ E-mail: dr_ckakpinar@hotmail.com

Received: $18.08 .2018 \quad$ Accepted: 16.10.2018

This article should be cited as following: Akpınar C. K, Özdemir A.Ö. Free-floating thrombus in the carotid artery: two different etiologies and treatment approaches Turkish Journal of Cerebrovascular Diseases 2019; 25 (2): 129-133. doi:10.5505/tbdhd.2018.73636 


\section{CASE I}

A 36-year-old male patient underwent a spinal surgery (laminectomy) in the lumbar region following an in-vehicle traffic accident and was referred to our hospital with the diagnosis of acute ischemic stroke with complaints of speech impairment and loss of strength on the right side 10 hours after surgery. The patient had no known risk factors other than hypertension and diabetes mellitus. National Institute of Health Stroke Scale (HIHSS) score was 16. Alberta stroke program early computed tomography score (ASPECT) was 9. Diffusion magnetic resonance imaging (MRI) showed cortical-subcortical embolic infarcts in the left external border zone and middle cerebral artery (MCA) irrigation area. The patient was taken directly to the angiography suite as the brain tomography angiography device was defective. In DSA, a thrombus formation $(2.5 \times 1.1 \mathrm{~cm})$ was found allowing flow in the middle part of the left common carotid artery (CCA) (Figure Ia). The 6F guiding catheter (DestinationTM, Terumo, Tokyo, Japan) was placed proximal to the common carotid. The thrombus was aspirated by repetitive manual aspirations by positioning the 6F distal access catheter (SofiaTM; Soft torqueable catheter Optimized For Intracranial Access; MicroVention, Tustin, California, USA) proximal to the thrombus in the CCA and by advancing it distally. There was no distal embolism in the cranial images obtained after aspiration and the thrombus in the CCA was completely aspirated (Figure Ib).The patient who was diagnosed with hyperhomocysteinaemia in the etiological examination [56 micromol/liter (Normal range 5-12 micromol/liter)] was initiated on warfarin therapy to maintain international normalized ratio (INR) 2-3. The modified Rankin score (mRS) in the 3rd month polyclinic control was 2 .

\section{CASE II}

A 55-year-old male patient applied to the emergency department with complaints of impaired speech and right side weakness that started two hours ago. Admission NIHSS was 18. There was no known disease other than hypertension as a risk factor. ASPECT score was 9. Diffusion MRI revealed cortical-subcortical infarcts in the left middle cerebral artery (MCA) irrigation area. Computed tomography (CT) angiography revealed a thrombus of $2 \mathrm{~cm}$ in length $(2 \times 1 \mathrm{~cm})$ in the origin of left internal carotid artery (ICA), which caused a filling defect in the lumen (Figure IIa), and there was no intracranial occlusion. The patient was administered with IV recombinant tissue plasminogen activator ( $\mathrm{r}-\mathrm{tPa}$ ) at a dose of $0.9 \mathrm{mg} / \mathrm{kg}$. A clinical progression was observed 16 hours after treatment and there was no hemorrhage in the control CT. Diffusion MRI showed increased infarcts in the left MCA irrigation area. The doppler ultrasonography performed 24 hours after r-tPA showed a freefloating thrombus causing $70 \%$ stenosis in the left ICA. The patient was initiated on 25,000 units of unfractionated heparin infusion as IV, and on the third day the warfarin was added to the treatment. The treatment dose was adjusted to maintain INR $2-3$, and the patient was discharged. The thrombus at the origin of ICA completely disappeared in the carotid doppler performed on 10th day and in DSA repeated on 20th day (Figure IIb). The patient had a persistent and high sedimentation rate at 100 $\mathrm{mm} / \mathrm{h}$ (normal range $0-20 \mathrm{~mm} / \mathrm{h}$ ) and CRP 180 $\mathrm{mg} / \mathrm{L}$ (normal range $0-8 \mathrm{mg} / \mathrm{L}$ ) at his admission and in his blood tests that were repeated after.Thoracic tomography performed for etiologic investigations revealed an appearance that may be consistent with tuberculosis, and the results of the examinations made in this aspect $(4+$ bacilli were detected in acid-resistant bacteria direct examination) supported tuberculosis. The patient was transferred to the Department of Chest Diseases and appropriate treatment was started for tuberculosis. The treatment was adjusted as acetylsalicylic acid $100 \mathrm{mg} /$ day. The mRS score in 3rd month was 3.

\section{DISCUSSION}

Free-floating thrombus in the artery is a condition that is attached to the wall of the artery and extends along the wall, and where cyclic blood flow continues at its distal end and is rarely seen. Its incidence is between $0.05-1.45 \%$ (1). This rate is probably higher, but in most cases the diagnosis cannot be made because of insufficient investigations. DSA is an important guide in the differentiation of intraluminal thrombus that develops due to atherosclerotic stenosis or dissection, that's in determining its etiology, and in 


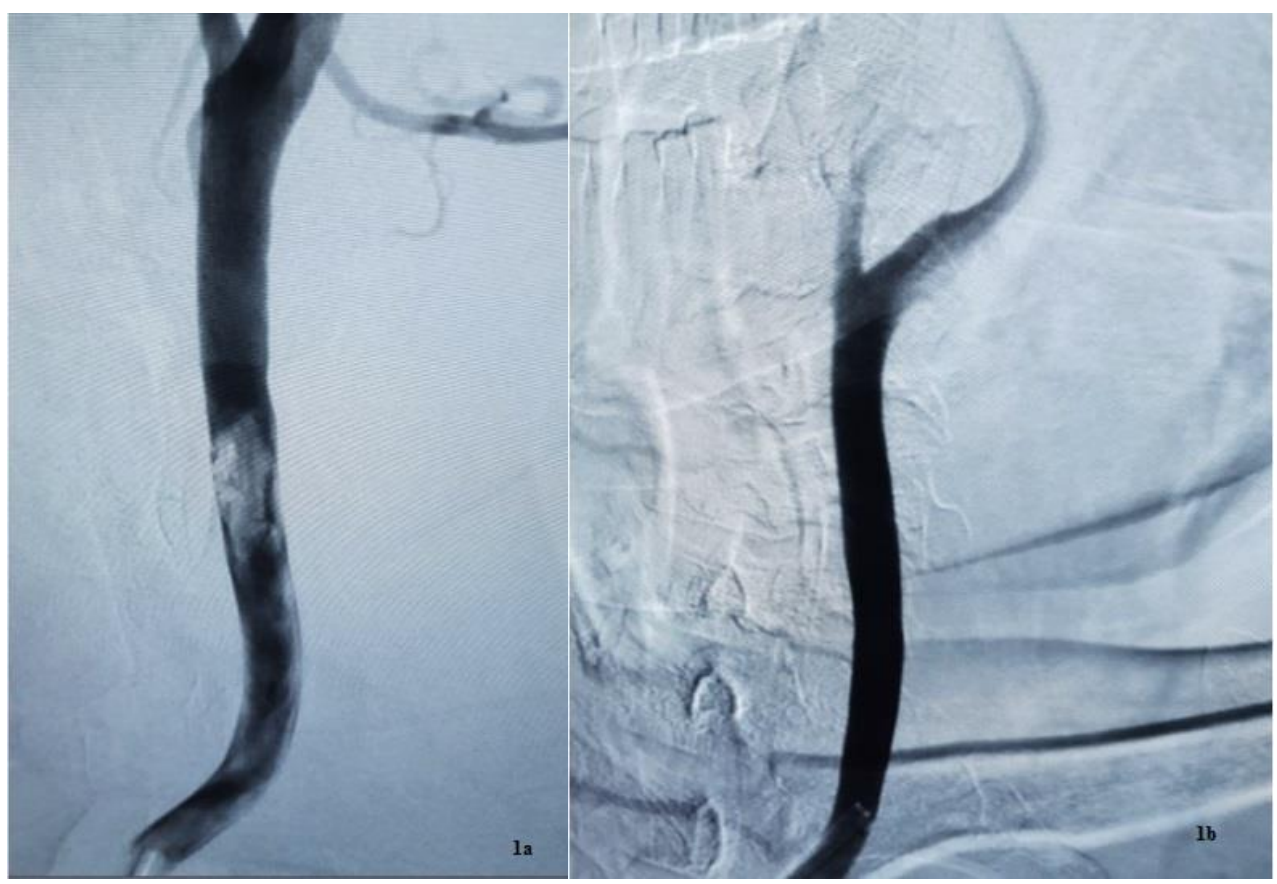

Figure I. (a) Thrombus causing intraluminal filling defect in left common carotid artery on DSA anteroposterior imaging, (b) Complete recanalization of thrombus in left common carotid artery after mechanical thrombectomy on DSA anteroposterior imaging.

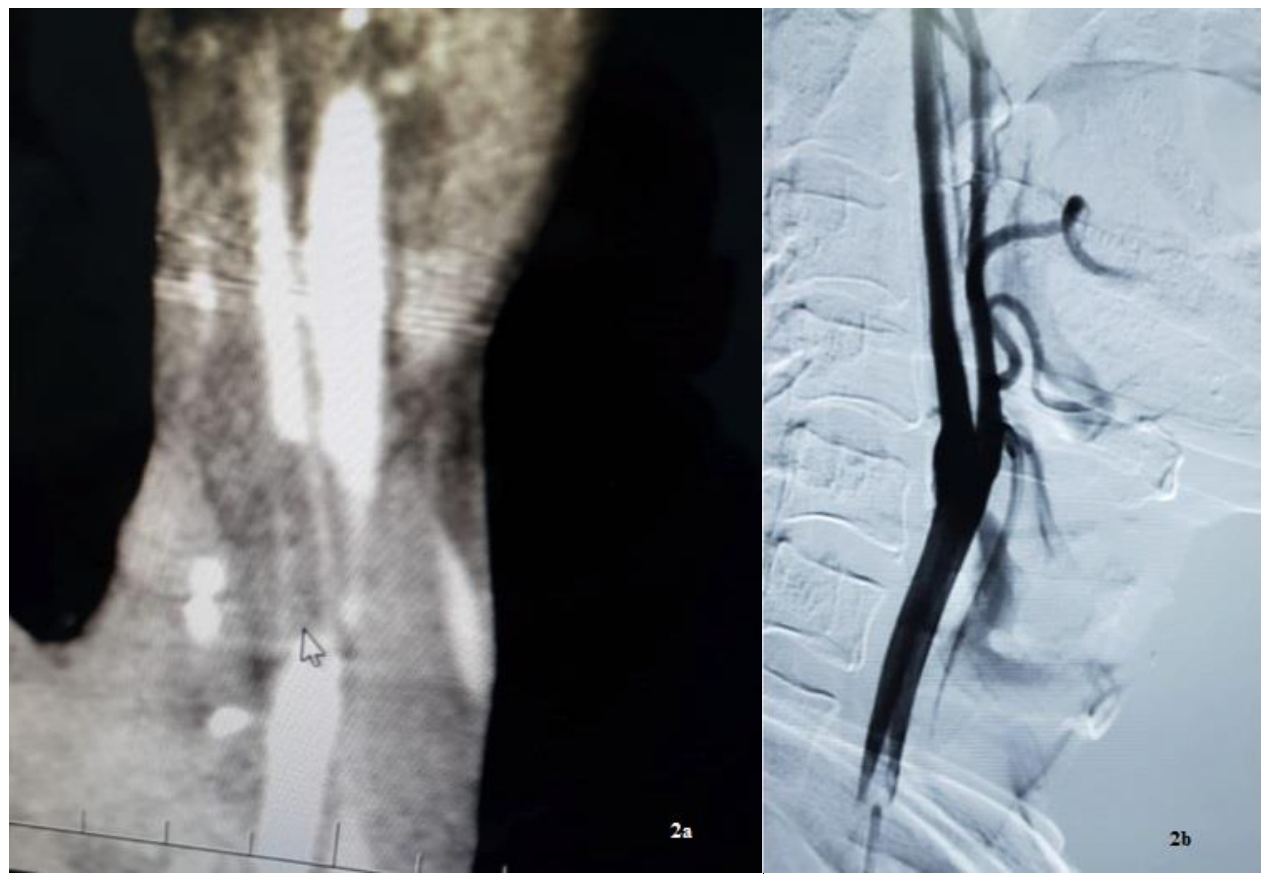

Figure II. (a) Thrombus in the origin of ICA, approximately $2 \mathrm{~cm}$ long, with distal extension leading to an intra-luminal filling defect, on Neck CT angiography in sagittal sections (white arrow), (b) Complete disappearance of thrombus in left common carotid artery after medical treatment, on DSA lateral imaging. 
the management of acute/chronic treatment (2). The presence or absence of carotid stenosis does not increase the incidence and development of free-floating thrombus (11).

The most common underlying cause is atherosclerosis, while other causes include hypercoagulation, autoimmune diseases, carotid artery aneurysm, dissection, cardiogenic embolism, cancer and trauma (6-9). While hyperhomocysteinemia was found to be the cause of hypercoagulation in our first case, whereas for our second case the cause thereof was found to be tuberculosis.

In most of cases (74\%), the affected area is cervical ICA, followed by common carotid artery (12). The affected area was cervical ICA in one case, and common carotid artery in another case. Free-floating thrombus causes acute neurological findings as a result of embolic strokes and may show frequent recurrence $(6,13)$. Free-floating thrombus may contain various pathologies such as intraluminal thrombus, plaque thrombus, and embolic thrombus (14). Both of our cases applied with acute onset neurological finding and progression was observed in our second case who was administered with r-tPA. No progression was observed in our case who was treated with endovascular treatment.

The guides do not contain sufficient information on the treatment of free-floating thrombus in the carotid artery. The treatment method to be applied to reduce morbidity and mortality is very important. There is no randomized study comparing medical (antiaggregant and/or anticoagulant) and operational (stent, angioplasty, operational thrombectomy, endarterectomy, aspiration thrombectomy, mechanical thrombectomy) treatment (15). Therefore, there is no consensus on the treatment strategy. In a review where 145 patients were evaluated, no superiority of medical treatment to operational treatment was demonstrated. Generally, operative procedures were performed in patients with insufficient response to anticoagulant therapy (3). Although there are successful cases with anticoagulant and/or antiaggregant treatment (16), anticoagulation is recommended as the first-line treatment (17). While surgical treatment option was preferred primarily for treatment in the past years, whereas it is not preferred as the first treatment option today (13). Although mechanical thrombectomy is a standard treatment for proximal vascular occlusions (18), the effect of mechanical thrombectomy in intraluminal nonocclusive vascular narrowing (free-floating thrombus) of the carotid artery is not clear. However, recent studies showed that both aspiration-thrombectomy (19) and mechanical thrombectomy (15) are successful. Due to risk of distal embolism of free-floating thrombus, r-tPA was used in a few cases in the literature. Vanacker et. al. showed in their study that the free-floating thrombus disappeared completely in 5 cases and partially disappeared in 1 case and progression was observed in one case, out of 7 cases who were administered with r-tPA (20). In the first case, free-floating thrombus was completely recanalized by mechanical thrombectomy, whereas in the second case thrombus was partially resorbed by $r$ tPA. After clinical progression, IV unfractionated heparin infusion was initiated. On the 20th day, the DSA showed that the free-floating thrombus disappeared almost completely.

Randomized studies may reveal the superiority of endovascular treatment. However, using a balloon guiding catheter maybe a more appropriate approach to reduce the risk of distal embolism in such cases.

\section{REFERENCES}

1. Fitzpatrick N, Motyer r, Gibney B, et al.J NeuroIntervent Surg epub ahead of print:doi:10.1136/ neurintsurg-2018013946

2. Elijovich L, Kazmi K, Gauvrit JY, et al.The emerging role of multidetector row CT angiography in the diagnosis of cervical arterial dissection:preliminary study.Neuroradiology 2006; 48:606-612.

3. Bhatti AF, Leon Lr, Labropoulos $\mathrm{N}$, et al.Free-floating thrombus of the carotid artery:literature review and case reports.J Vasc Surg 2007; 45:199-205.

4. Buchan A, Gates P, Pelz D, et al.“Intraluminal thrombus in the cerebral circulation implications for surgical management," Stroke 1988; 19:681-687.

5. Urbano LA, Perren F, Rosstti A0, et al.images in cardiovascular medicine.Thrombus in the internal carotid artery complicating an 'unstable' atheromatous plaque.Circulation 2003; 107:19-20.

6. Roy M, Roy AK, Desanto Jr, et al.Free floating thrombus in carotid artery in a patient with recurrent strokes.Case Rep Med 2017; 2017:1-4.

7. Bhatti aF, Leon Lr, Labropoulos $\mathrm{N}$, et al.Free-floating thrombus of the carotid artery:literature review and case reports.J Vasc Surg 2007; 45:199-205.

8. Graham R, Blaszczynski M.Spontaneous free floating carotid artery thrombosis.BMJ Case Rep 2013. doi:10.1136/bcr-2013-008710 
9. Watanabe $\mathrm{M}$, Mori $\mathrm{T}$, Imai $\mathrm{K}$, et al.Distal migration of a floating carotid thrombus in a patient using oral contraceptives:a case report.J Med Case Rep 2009; 3:8389.

10. Combe J, Poinsard P, Besancenot J, et al.Free- floating thrombus of the extracranial internal carotid artery.Ann Vasc Surg 1990; 4:558-562.

11. Roy M, Roy AK, DeSanto JR, et al.Free Floating Thrombus in Carotid Artery in a Patient with Recurrent Strokes.Case Rep Med 2017;2017:4932567.doi:10.1155/2017/4932567.

12. Afsharfard A, Gholizadeh B, Abdolalian Y, et al.Carotid freefloating thrombus causing stroke in a young woman with lupus anticoagulant:a case report and review of the literature.Int J Surg Case Rep 2017; 33:35-37.

13. Fitzpatrick N, Motyer R, Gibney B, et al.Expanding the role of stent-retriever endovascular thrombectomy:a case series of free-floating thrombus.J Neurointerv Surg. 2018 Jun 20.pii:neurintsurg-2018013946.doi:10.1136/neurintsurg-2018-013946.

14. Hill SL, Brozyna W.Extensive free-floating thrombus of the internal carotid artery:a case report, treatment options and a review of literature. Am Surg 2005; 71:853-855.
15. Giragani S, Balani A, Agrawal V.Stentriever thrombectomy with distal protection device for carotid free floating thrombus:a technical case report.J Neurointerv Surg 2017 Aug;9(8):e33.doi:10.1136/neurintsurg-2016-012904.

16. Szendro G, Sabetai MM, Tegos T], et al.Free-floating carotid plaques:the natural history of two asymptomatic and nonoperated cases.J Vasc Surg 1999; 30:357-362.

17. Vellimana A, Kadkhodayan Y, Rich K, et al.Symptomatic patients with intraluminal carotid thrombus:outcome with a strategy of initial anticoagulation.J Neurosurg 2013; 118:34-41.

18. Goyal M, Menon BK, van Zwam WH, et al.endovascular thrombectomy after 16 large-vessel ischaemic stroke:a meta-analysis of individual patient data from five

19. Otawa M, Kinkori T, Watanabe K, et al.A case of carotid free-floating thrombus treated by carotid ultrasonographyguided endovascular approach.[Article in Japanese].No Shinkei Geka 2016; 44:489-494.(Abstract)

20. Vanacker P, Cordier M, Janbieh J, et al.Floating Arterial Thrombus Related Stroke Treated by Intravenous Thrombolysis.Cerebrovasc Dis 2014; 38:117-120. 